\title{
STRATEGI LAYANAN BIMBINGAN DAN KONSELING DALAM MEREDUKSI SIKAP NEGATIF TENTANG SEKS BEBAS
}

\author{
Ariadi Nugaraha ${ }^{1}$ \\ ${ }^{1}$ Fakultas Keguruan dan Ilmu Pendidikan, Universitas Ahmad Dahlan \\ ariadi.nugraha@bk.uad.ac.id
}

\begin{abstract}
Abstrak
Permasalahan remaja yang banyak disoroti saat ini menyangkut seks bebas. Sikap remaja terhadap seks bebas sangat beragam. Tujuan penelitian ini adalah mengetahui sikap siswa terhadap seks bebas serta bagaimana peran bimbingan dan konseling. Metode penelitian adalah survai. Subyek penelitian adalah siswa SMP di kabupaten Sleman. Jumlah subyek 466 siswa yang diambil secara random sampling. Hasil penelitian ini, diperoleh data bahwa siswa SMP di Kabupaten Sleman lebih dari 50\% responden memiliki sikap yang setuju terhadap seks bebas. Dari aspek biologis, $71 \%$ responden tergolong sangat setuju terhadap perilaku seks bebas, 55\% tergolong sangat setuju dari aspek psikologis dan $61 \%$ sangat setuju dari aspek sosial. Ini berarti bahwa sebagian besar responden yaitu siswa SMP di Kabupaten Sleman memiliki sikap yang kurang baik terhadap perilaku seks bebas. Bimbingan dan konseling bertujuan memfasilitasi siswa dapat berkembang optimal. Bentuk fasilitasi mengembnagkan siswa melalaui empat komponen layanan yaitu layanan dasar, responsif, peminatan perencanaan individual dan dukungan sistem. Strategi layanan bimbingan dan konseling yang dapat digunakan dalam mereduksi sikap negatif siswa adalah layanan dasar seperti bimbingann klasikal, bimbingan kelompok dan pengembangan media inovatif. Layanan responsif seperti konseling individu, konseling kelompok dan konseling sebaya. Dukungan sistem dapat berupa parenting class bagi orangtua, kolaborasi dengan BKKKBN dan Puskesmas tentang bahaya Seks bebas.
\end{abstract}

Kata kunci: strategi layanan, bimbingan, konseling, sikap, seks bebas

\begin{abstract}
The issue of teenagers that are mostly highlighted today is about free sex. The attitude of adolescents to free sex is very diverse. The purpose of this study was to determine students' attitudes toward sex and the role of guidance and counseling. The research method is survey. Subjects were junior high school students in the district of Sleman. Number of subjects 466 students drawn by random sampling. $\mathrm{H}$ acyl this study, data showed that junior high school students in Sleman more than 50\% of respondents had an attitude in favor of the free sex. From the biological aspect, $71 \%$ of respondents strongly agreed pertained to free sex, 55\% classified as very agree on the psychological aspects and $61 \%$ strongly agree on the social aspect. This means that most of the respondents are students of junior high school in Sleman have unfavorable attitudes towards sex behavior. Guidance and counseling aimed at facilitating students can develop optimally. Forms of facilitation mengembnagkan students melalaui four service components, namely the basic service, responsiveness, specialization individual planning and support system. Strategic guidance and counseling services that can be used in reducing the negative attitude of students is the basic services such as bimbingann classical, group counseling and the development of innovative media. Responsive services such as individual
\end{abstract}


counseling, group counseling and peer counseling. Support system can be a parenting class for parents, collaboration with BKKKBN and health centers about the dangers of free sex.

Keywords: service strategy, guidance, counseling, attitude, free sex

\section{PENDAHULUAN}

Peserta didik sebagai individu sedang berada dalam proses berkembang atau menjadi (becoming), yaitu berkembang ke arah kematangan atau kemandirian. Untuk mencapai kematangan tersebut, peserta didik memerlukan bimbingan, karena mereka masih kurang memiliki pemahaman atau wawasan tentang dirinya dan lingkungannya juga pengalaman dalam menentukan arah kehidupannya (Caraka \& Nindiya, 2015: 55).

Perkembangan peserta didik tidak terlepas dari pengaruh lingkungan baik fisik, psikis maupun sosial. Sifat inherent lingkungan adalah perubahan. Perubahan yang terjadi dalam lingkungan dapat mempengaruhi gaya hidup (life syle) warga masyarakat. Apabila perubahan yang terjadi itu sulit diprediksi, atau di luar jangkauan kemampuan, maka akan melahirkan diskontinuitas perkembangan perilaku individu, seperti terjadi stagnasi (kemandegan) perkembangan, masalah-masalah pribadi atau penyimpangan perilaku. Perubahan lingkungan yang diduga mempengaruhi gaya hidup, dan diskontinuitas perkembangan tersebut diantaranya: ledakan penduduk, pertumbuhan kota-kota, kesenjangan tingkat sosial ekonomi masyarakat, revolusi informasi, pergeseran fungsi atau struktur keluarga, dan perkembangan struktur masyarakat dari agraris ke industri. Iklim lingkungan yang kurang sehat ternyata mempengaruhi perkembangan pola perilaku atau gaya peserta didik (remaja) yang cenderung menyimpang dari kaidahkaidah moral, seperti pelanggaran tata tertib sekolah, tawuran, meminum minuman keras, penyalahgunaan obat-obat terlarang, kriminalitas, dan pergaulan bebas.

Masa remaja merupakan suatu periode dalam kehidupan manusia dimana terjadi transisi secara fisik dan psikologis yang umumnya berlangsung selama periode pubertas hingga dewasa muda (MerriamWebster Dictionary, 2012). Remaja sebagai penerus kehidupan perlu mendapat perhatian karena pada masa ini menentukan bagaimana remaja menghadapi kehidupan selanjutnya yaitu masa awal kedewasaan. (Hunainah 2011:1) . Pola Karakteristik pesatnya tumbuh kembang ini menyebabkan remaja memiliki rasa keingintahuan yang besar, menyukai petualangan dan tantangan serta cenderung berani mengambil risiko tanpa pertimbangan yang matang (Soetjiningsih, 2004).

Tantangan utama masa remaja adalah perubahan yang berkaitan dengan perkembangan masa pubertas dan seksualitas, 
perubahan peran sosial, perkembangan kognitif, emosi dan moral, serta transisi sekolah. (Perkins \& Borden, 2003). Permasalahan remaja yang banyak disoroti saat ini menyangkut seks bebas. Penyebaran penyakit kelamin, kehamilan di luar nikah, aborsi dan pernikahan usia muda. Sullivan (Hall \& Lindzey, 1985:184) mengemukakan bahwa banyak konflik masa remaja yang timbul dari kebutuhan-kebutuhan akan kepuasan seksual, keamanan, dan keakraban yang saling berlawanan. Selama masa remaja, baik perempuan maupun laki-laki seringkali mempertanyakan seksualitas mereka dan mencoba menentukan perasaan-perasan seksulanya sendiri tanpa melibatkan orang lain. Sebagian remaja lain mencoba mengenali dan mengekspresikan perasaan seksualnya dengan melakukan eksperimentasi atau coba-coba, sehingga berpotensi munculnya masalah penyimpangan perilaku seksual dan kepribadian remaja.

Berdasarkan hasil penelitian perilaku seks bebas sebagai salah satu perilaku yang menyimpang remaja dari tahun ke tahun semakin beresiko, masyarakat mulai membicarakan ketika muncul fakta bahwa 74,89\% remaja di Kupang, Cirebon, Palembang, Singkawang, Tasikmalaya berhubungan seks dengan pacar mereka (Sustiwi, 2005:15) Remaja mulai dipersalahkan, dituduh tidak sopan, tidak bermoral, tidak berakhlak bahkan sampai dikatakan tidak beragama.

Meningkatnya minat seksual pada remaja akibat mereka tidak mendapatkan pendidikan kesehatan reproduksi, sehingga tidak mengetahui bahaya atau dampak dari seks bebas. Remaja pada umunya memiliki rasa ingin tahu yang besar tentang seksualitas sehingga mendorong bagi remaja itu sendiri untuk selalu berusaha mencari informasi, terlepas benar tidaknya informasi tersebut. Sumber informasi tersebut diperoleh dengan bebas mulai dari teman sebaya, buku-buku, video, maupun membuka situs-situs lewat internet.

Penampilan perilaku remaja seperti diatas tidak diharapkan, karena tidak sesuai dengan sosok pribadi manusia Indonesia yang dicita-citakan, seperti tercantum dalam tujuan pendidikan nasional (UU No. 20 Tahun 2003), yaitu : (1) beriman dan bertakwa terhadap Tuhan yang Maha Esa; (2) beakhlak mulia; (3) memiliki pengetahuan dan ketrampilan; (4) memiliki kesehatan jasmani dan rohani; (5) memiliki kepribadian yang mantap dan mandiri; (6) memiliki rasa tanggung jawab kemasyarakatan dan kebangsaan.

Pendidikan memiliki fungsi pengembangan, membantu individu mengembangkan diri sesuai dengan fitrahnya (potensi), peragaman (differensiasi), membantu individu memilih arah perkembangan yang tepat sesuai dengan potensi dan integrasi, membawa keragaman perkembangan ke arah tujuan yang sama sesuai dengan hakikat manusia untuk menjadi pribadi yang utuh (Sunaryo Kartadinata, 2011:57). Upaya bimbingan dan konseling dalam merealisasikan fungsi-fungsi pendidikan seperti disebutkan terarah 
kepada upaya membantu individu, untuk memperhalus, menginternalisasi, memperbaharui, dan menginternalisasi sistem nilai ke dalam perilaku mandiri.

Bimbingan, sebagai upaya pendidikan, diartikan sebagai proses bantuan kepada individu untuk mencapai tingkat perkembangan diri secara optimum di dalam navigasi hidupnya secara mandiri. Bantuan dalam arti bimbingan yaitu memfasilitasi individu untuk mengembangkan kemampuan memilih dan mengambil keputusan atas tanggung jawab sendiri. Kondisi perkembangan optimum adalah kondisi dinamis yang ditandai dengan kesiapan dan kemampuan individu untuk memperbaiki diri (self-improvement) agar dia menjadi pribadi yang berfungsi penuh (fullyfungctioning) di dalam lingkungannya (Sunaryo Kartadinata, 2011:57)

Tujuan utama layanan bimbingan dan konseling di sekolah adalah memberikan dukungan pada pencapaian kematangan kepribadian, keterampilan sosial, kemampuan akademik, dan bermuara pada terbentuknya kematangan karir individual yang diharapkan dapat bermanfaat di masa yang akan datang (Fatur Rahman, 2012:4). Namun demikian, implementasi layanan bimbingan dan konseling yang ideal tersebut berhadapan dengan berbagai hambatan dan sejumlah kendala serius. Berbagai hambatan dan kendala tersebut, seperti: tujuan bimbingan dan konseling tidak selaras dengan tujuan pendidikan, bimbingan dan konseling masih berorientasi pada masalah, penyusunan program belum berdasarkan needs assessment, minimnya dukungan dari pejabat sekolah terhadap program bimbingan dan konseling, belum dipahaminya paradigma hubungan kolaborasi antar profesi dalam satuan pendidikan dan kurang adanya respon yang positif dari peserta didik terhadap layanan bimbingan dan konseling.

Menurut Brown \& Trusty (dalam Fathur : 2009:8) Penelitian yang dilakukan oleh ASCA (American School Counselor Association) menunjukkan bahwa sebagian besar konselor sekolah menghabiskan waktu antara 1 sampai $88 \%$ dari keseluruhan waktu bekerja hanya untuk kegiatan-kegiatan yg tidak profesional dan tidak ada kaitanya langsung denngan layanan BK. Menurut Sunaryo (dalam Fathur 2012:11) kegiatan layanan bimbingan dan konseling di sekolah yang berkembang di Indonesia selama ini lebih terfokus pada kegiatan-kegiatan yang bersifat administratif dan klerikal, seperti mengelola kehadiran dan ketidakhadiran siswa, mengenakan sanksi disiplin pada siswa yang terlambat dan dianggap nakal.

Menurut tim penulis buku Penataan Pendidikan Profesional Konselor dan Layanan bimbingan dan Konseling dalam Jalur Pendidikan Formal, (2007:194) pada saat ini telah terjadi perubahan paradigma pendekatan bimbingan dan konseling, yaitu dari pendekatan yang berorientasi tradisional, remedial, klinis, dan terpusat pada konselor, kkepada pendekatan yang berorientasi perkembangan dan 
preventif. Pendekatan bimbingan dan konseling perkembangan (Developmental Guidance and Counseling) atau bimbingan dan konseling komprehensif (Comprehensive Guidance and Counseling) didasarkan pada upaya pencapaian tugas perkembangan, pengembangan potensi, dan pengentasan masalah-masalah konseli. Tugas-tugas perkembangan dirumuskan sebagai standar kompetensi yang harus dicapai konseli, sehingga pendekatan ini disebut juga bimbingan dan konseling berbasis standar (Standard Based Guidance and Counseling). Ketika pendekatan bimbingan dan konseling perkembangan dipergunakan akan menggabungkan pendekatan yang berorientasi klinis, remidial, dan preventif, (Myrick, 2011:8).

Menurut Supriatna (2011), bimbingan dan konseling komprehensif merupakan model bimbingan dan konseling yang berpegang pada prinsip bimbingan dan konseling perkembangan. Bimbingan dan konseling perkembangan bertolak dari asumsi bahwa perkembangan yang sehat terjadi melalui interaksi yang sehat antara individu dengan lingkungannya. Ini berarti bahwa pengembangan lingkungan perkembangan atau ekologi perkembangan manusia merupakan wahana strategis perkembangan siswa yang harus dikembangkan konselor. Lingkungan perkembangan adalah lingkungan belajar yang terstruktur dan secara sengaja dirancang untuk memberi peluang kepada siswa mempelajari perilaku baru, membentuk ekspektasi dan persepsi, memperbaiki dan bahkan mengganti perilaku yang tidak sesuai, memperhalus dan menginternalisasi perilaku.

Menurut Dede Rahmat Hidayat (2013: 108), model bimbingan dan konseling komprehensif merupakan respons terhadap berbagai penelitian yang telah dilakukan oleh American School Counseling Association (ASCA). Meskipun model ini diadopsi dari model ASCA di Amerika Serikat, namun model ini dapat diadaptasi di Indonesia. Kemungkinan adaptasi model ASCA di Indonesia sangat terbuka, karena model ini memberikan kerangka berpikir dan kerangka kerja yang fleksibel. Dengan fleksibilitas tersebut, model ini dapat diadaptasi untuk pengembangan bimbingan dan konseling di Indonesia.

Profesi bimbingan dan konseling di Indonesia dewasa ini telah mengalami perkembangan dan peningkatan eksistensi yang semakin kokoh. Akan tetapi, masih ada beberapa persoalan yang berkaitan dengan implementasi bimbingan dan konseling dimana pekerjaan dalam layanan bimbingan dan konseling lebih merupakan pekerjaan administratif, seperti pengecekan kehadiran siswa, pemberian sanksi keterlambatan, pencatatan poin pelanggaran siswa, dan lain sebagainya. Selain itu, juga masih terdapat kesenjangan antara harapan dan realita kondisi peserta didik sebagai objek bimbingan. Hal ini menjadi kebutuhan nyata akan perlunya penataan kerangka kerja bimbingan dan konseling untuk menjadi suatu layanan profesional, efektif dan proaktif. 
Menurut Sunaryo Kartadinata (2010), perkembangan model penyelenggaraan bimbingan dan konseling yang dicapai pada akhir abad 20 telah menunjukkan identitas profesi yang semakin kokoh. Model bimbingan dan konseling (perkembangan) komprehensif adalah model yang menaruh perhatian penuh kepada seluruh peserta didik, bekerja bersama dengan orang tua, guru, administrator, dan stakeholder lainnya. Riset yang berbasis pada model komprehensif memberikan penguatan untuk dikokohkannya model ini sebagai model bimbingan dan konseling di sekolah, namun masih belum tersosialisasikan kepada seluruh sekolah dan belum menjadi kebijakan nasional, substansi bimbingan dan konseling masih memerlukan pengembangan. Arah perkembangan ini perlu ditindaklanjuti dan ditegaskan dalam agenda abad 21 .

Untuk dapat merealisasikan pengembangan model bimbingan dan konseling komprehensif di abad 21 tidaklah mudah. Upaya pengembangan sudah harus dirintis dan dipersiapkan mulai dari sekarang. Apalagi, sekarang ini berlaku kurikulum 2013 sebagai pedoman penyelenggaraan pendidikan di Indonesia. Bimbingan dan konseling juga harus berkontribusi dalam implementasi kurikulum ini dengan menggunakan model bimbingan dan konseling komprehensif.

Menurut Sunaryo Kartadinata (2015), bimbingan dan Konseling dalam kurikulum 2013, secara filosofis, konseptual dan legal formal dituangkan dalam Permendikbud No. 111 Tahun 2014 tentang Bimbingan dan Konseling pada Pendidikan Dasar dan Pendidikan Menengah. Permendikbud ini adalah payung hukum eksistensi dan acuan utama dalam penyelenggaraan bimbingan dan konseling dalam Sistem Pendidikan Nasional di Indonesia, khususnya pada jalur pendidikan formal jenjang Pendidikan Dasar dan Menengah.

Komponen Layanan Bimbingan dan Konseling Komprehensif yaitu Layanan Dasar, sebagai pemberian bantuan melalui kegiatan penyiapan pengalaman terstruktur secara klasikal atau kelompok yang dirancang dan dilaksanakan secara sistematis dalam rangka mengembangkan kemampuan penyesuaian diri yang efektif sesuai dengan tahap dan tugas perkembangan. Strategi layanan dasar yaitu 1) bimbingan klasikal, 2) bimbingan kelompok, 3) media bimbingan kelompok, 4) asesmen kebutuhan.

Layanan Peminatan dan Perencanaan Individual, sebagai bantuan untuk merumuskan dan melakukan aktivitas-aktivitas sistematik yang berkaitan dengan perencanaan masa depan berdasarkan pemahaman tentang kelebihan dan kekurangan dirinya, peluang dan kesempatan yang ada di lingkungan. Stetategi layanan perencanaan individual dan peminatan berupa layanan peminatan dalam format individu maupun kelompok untuk membantu siswa merecanakan pendidikan lanjutan serta perencanaan karir. 
Layanan responsif, sebagai proses bantuan untuk menghadapi masalah dan memerlukan pertolongan dengan segera, supaya peserta didik tidak mengalami hambatan dalam pencapaian tugastugas perkembangan. Strategi layanan responsif dapat berupa konseling individu, konseling keleompok, dan lain sebagainya. Dukungan sistem, sebagai proses bantuan atau fasilitasi atau dukungan secara tidak langsung terhadap kelancaran, efektivitas dan efisisen pelaksanaan layanan bimbingan dan konseling.

\section{METODE PENELITIAN}

Penelitian ini merupakan penelitian survei. Subyek penelitian adalah siswa Sekolah Menengah Pertama di Kabupaten Sleman yang bukan anggota PIK-R. Dari 21 Sekolah yang memiliki PIK-R, akan diambil secara purposvie sampling yaitu dengan kriteria pada sekolahsekolah yang PIK-R aktif, rutin mengadakan kegiatan tentang Triad KRR, serta memiliki struktur organisasi PIK-R yang beregenerasi secara periodik tertentu. Sedangkan pengambilan sampel subjek penelitian dengan teknik random sampaling sampai memenuhi jumlah responden.

Instrumen penelitian adalah angket. Dilihat cara menjawab yaitu skala psikologi untuk mengukur sikap. Hasil ujicoba instrumen uji validitas menunjukkan ada 51 item valid dari 61 item yang ada. Hasil uji reliabilitas menunjukkan skor, 0,796 artinya instrumen memiliki tingkat relaibilitas yang tinggi sehingga layak gunakan untuk penelitian. Analisis data menggunakan data menggunakan metoda analisis statistik deskriptif berbantuan program aplikasi SPSS.

\section{HASIL DAN PEMBAHASAN}

Tujuan penelitian ini adalah untuk mengetahui sikap siswa SMP di Kabupaten Sleman terhadap seks bebas. Setelah penelitian dilakukan, amaka dapat diuraikan sebagai berikut

Tabel 1. Kriteria Penilaian

\begin{tabular}{llc}
\hline \multicolumn{1}{c}{ Kategori } & \multicolumn{1}{c}{ Interval } & Frekuensi \\
\hline Sangat Tinggi & $\mathrm{X} \geq 223,177$ & 84 \\
\hline Tinggi & $223,177 \geq \mathrm{X} \geq 207,76$ & 241 \\
\hline Rendah & $207,76 \geq \mathrm{X} \geq 192,347$ & 183 \\
\hline Sangat Rendah & $\mathrm{X} \leq 223,180$ & 86 \\
\hline
\end{tabular}

Tabel 1 menjelaskan bahwa jika seorang remaja mendapatkan skor yang lebih dari 223,177 berarti subjek mempunyai sikap terhadap perilaku seks bebas yang tergolong sangat setuju, jika subjek memiliki skor antara 223,177 - 207,76 maka responden mempunyai sikap tehadap perilaku seks bebas yang tergolong setuju, jika remaja memperoleh skor 
antara 207,76 - 192,347, maka berarti bahwa responden memiliki sikap terhadap perilaku seks bebas yang tergolong tidak setuju, dan jika responden mendapatkan skor lebih kecil atau sama dengan 223,180, maka responden mempunyai sikap remaja terhadap perilaku seks bebas yang tergolong sangat tidak setuju.
Dari data yang telah dikumpulkan, diperoleh data bahwa 84 responden sangat setuju terhadap seks bebas, 241 responden setuju terhadap seks bebas, 183 responden tidak setuju terhadap seks bebas dan 86 responden sangat tidak setuju terhadap seks bebas.

Tabel 2. Kriteria Jawaban Responden Berdasarkan Aspek

\begin{tabular}{|c|c|c|c|c|c|c|c|c|c|c|}
\hline \multirow{3}{*}{ ASPEK } & \multicolumn{8}{|c|}{ JAWABAN RESPONDEN } & \multirow{2}{*}{\multicolumn{2}{|c|}{ TOTAL }} \\
\hline & \multicolumn{2}{|c|}{ STS } & \multicolumn{2}{|c|}{ TS } & \multicolumn{2}{|c|}{$\mathbf{S}$} & \multicolumn{2}{|c|}{ SS } & & \\
\hline & $\mathbf{f}$ & $\%$ & f & $\%$ & $\mathbf{f}$ & $\%$ & $\mathbf{f}$ & $\%$ & $\mathbf{f}$ & $\%$ \\
\hline Aspek Biologis & 19 & $3 \%$ & 13 & $4 \%$ & 43 & $22 \%$ & 105 & $71 \%$ & 179.93 & $100 \%$ \\
\hline Aspek Psikologis & 41 & $7 \%$ & 24 & $8 \%$ & 58 & $30 \%$ & 82 & $55 \%$ & 205.73 & $100 \%$ \\
\hline Aspek Sosial & 38 & $6 \%$ & 22 & $7 \%$ & 50 & $25 \%$ & 90 & $61 \%$ & 200.46 & $100 \%$ \\
\hline JUMLAH & 99 & $17 \%$ & 59 & $20 \%$ & 151 & $77 \%$ & 277 & $187 \%$ & 586.12 & $300 \%$ \\
\hline
\end{tabular}

Sikap remaja terhadap perilaku seks bebas yang diungkap pada penelitian ini menggunakan 11 butir pernyataan dengan tiga aspek utama, yaitu aspek biologis, aspek psikologis, dan aspek sosial. Tabel 2 menjelaskan data sebagai berikut :

\section{Aspek biologis}

Presentase sikap siswa SMP terhadap seks bebas menurut aspek biologis menjelaskan bahwa 3\% sikap siswa SMP di Kabupaten Sleman tergolong sangat tidak setuju terhadap perilaku seks bebas, yang artinya secara biologis menolak perilaku seks bebas, $4 \%$ tergolong tidak setuju, yang artinya menolak perilaku bebas, $22 \%$ tergolong setuju terhadap perilaku bebas, dan $71 \%$ tergolong sangat setuju terhadap perilaku seks bebas.

\section{Aspek Psikologis}

Presentase sikap siswa SMP terhadap seks bebas menurut aspek psikologis menjelaskan bahwa 7\% sikap siswa SMP di Kabupaten Sleman tergolong sangat tidak setuju terhadap perilaku seks bebas, yang artinya secara psikologis menolak perilaku seks bebas, $8 \%$ 
tergolong tidak setuju, yang artinya menolak perilaku bebas, $30 \%$ tergolong setuju terhadap perilaku bebas, dan $55 \%$ tergolong sangat setuju terhadap perilaku seks bebas.

\section{Aspek Sosial}

Presentase sikap siswa SMP terhadap seks bebas menurut aspek sosial menjelaskan bahwa $6 \%$ sikap siswa SMP di Kabupaten Sleman tergolong sangat tidak setuju terhadap perilaku seks bebas, yang artinya secara sosial menolak perilaku seks bebas, $7 \%$ tergolong tidak setuju, yang artinya menolak perilaku bebas, $25 \%$ tergolong setuju terhadap perilaku bebas, dan $61 \%$ tergolong sangat setuju terhadap perilaku seks bebas.

Hasil penelitian di atas menggambarkan bahwa sikap siswa SMP di Kabupaten Sleman setuju dengan perilaku seks bebas. Hal ini ditunjukkan dari kriteria penilaian bahwa 86 responden sangat setuju terhadap seks bebas dan 241 responden setuju terhadap seks bebas. Sedangkan 183 responden tidak setuju seks bebas dan 86 responden sangat tidak setuju terhadap seks bebas. Ini berarti bahwa lebih dari 50\% responden setuju terhadap perilaku seks bebas. Dengan demikian, dapat disimpulkan bahwa sikap individu dalam hal ini siswa SMP di Kabupaten secara keseluruhan setuju terhadap perilaku seks bebas.

Sikap remaja dalam ini siswa SMP terhadap perilaku seks bebas dapat saja dipengaruhi oleh beberapa hal yaitu perubahan biologis, pengaruh pola asuh orang tua, pengaruh teman sebaya, perspektif akademik dan perspektif sosial kognitif (Kusmiran, 2012). Faktorfaktor yang mempengaruhi pembentukan sikap positif atau negatif adalah dari pengalaman pribadi karena sesuatu yang sedang dialami seseorang akan ikut membantu dan mempengaruhi penghayatan terhadap stimulus sosial pengaruh orang lain yang dianggap penting pada umumya individu cenderung untuk memiliki sikap yang konformasi atau searah dengan orang lain yang dianggap penting (Sugiono, 2009).

Sikap remaja terhadap seks bebas adalah sikap menolak atau menerima perilaku seks bebas pada remaja. Seorang remaja dalam penelitian ini dituntut untuk dapat menyikapi seks bebas dengan sikap yang tepat sehingga di dalam masyarakat dan kehidupan pribadinya tidak akan menerima dampak negatif seks bebas karena melakukannya. Sikap remaja terhadap seks bebas mempunyai dua aspek yaitu sikap pribadi dan sikap sosial. Sikap pribadi terhadap seks bebas adalah penerimaan secara pribadi terhadap seks bebas, yaitu menerima atau menolak perilaku seks bebas. Sikap sosial adalah sikap yang terjadi karena adanya norma dan aturan sosial yang ada di dalam masyarakat. Sebagai contoh, jika sikap seorang remaja terhadap perilaku seks bebas adalah menerima perilaku seks bebas, namun norma dan aturan sosial yang ada di masyarakat melarangnya bahkan menganggap itu perbuatan dosa, maka remaja menyesuaikan sikap pribadinya tersebut dengansikap 
yang diharapkan oleh lingkungan sosialnya tersebut sehingga sikapnya menolak perilaku seks bebas. Hasil penelitian yang dilakukan pada siswa SMP di Kabupaten Sleman menunjukkan bahwa siswa di sana mempunyai sikap terhadap seks bebas yang kurang baik. Mereka kurang dapat memahami apa itu seks bebas dan bagaimana dampaknya jika hal tersebut dilakukan, kurang mampu bertindak sesuai dengan peraturan yang ada dalam masyarakat, dan mempunyai keadaan psikis yang kurang baik terhadap perilaku seks bebas.

Sikap terhadap seks bebas yang kurang baik ini menggambarkan bahwa perlu dilakukan tindak lanjut terhadap siswa SMP di Kabupaten Sleman. Tindak lanjut yang dilakukan dapat berupa pemberian informasi kepada para siswa. Salah satu bentuk stimulus sikap dari luar adalah pengetahuan atau pemberian informasi. Remaja yang mendapat informasi yang benar tentang seksual pranikah (seks bebas) maka mereka akan cenderung mempunyai sikap positif. Seseorang setelah mengetahui stimulus atau objek kesehatan, kemudian mengadakan penilaian atau pendapat terhadap apa yang diketahui, proses selanjutnya diharapkan akan dapat melaksanakan atau mempraktekkan apa yang diketahui atau disikapi sehingga pengetahuan seksual pranikah (seks bebas) dapat mempengaruhi sikap individu tersebut terhadap seksual pranikah (seks bebas) (Notoatmodjo, 2007).

Sikap merupakan aspek psikis yang dipelajari, maka sikap itu dapat berubah. Perubahan tidak terjadi dengan sendiirnya, akan tetapi dipengaruhi oleh faktor-faktor tertentu. McGueire (Syamsu Yusuf \& Juntika, 2008:172) salah satu teori mengenai perubahan sikap yaitu dari pendekatan teori belajar (learning teory approach) pendekatan ini beranggapan, bahwa sikap itu berubah disebabkan oleh proses belajar atau materi yang dipelajari.

Bimbingan Perkembangan menggunakan titik pandang perkembangan dengan alasan bahwa layanan bimbingan dan konseling tidak hanya berurusan dengan perilaku maladaptif dan mencegah perilaku perilaku maladaptif tersebut, namun yang lebih penting adalah menyangkut upaya memfasilitasi peserta didik agar mampu mengembangkan potensi dirinya. Konsekuensi pandangan perkembangan yaitu layanan bimbingan dan konseling tidak hanya disediakan bagi siswa di sekolah, tetapi seluruh individu dalam organisasi dan kultur asal peserta didik, karena perkembangan yang sehat dan optimum individu akan terjadi dalam lingkungan yang sehat. Pendekatan perkembangan dalam bimbingan dan konseling menuntut bimbingan dan konseling memberikan layanan secara proaktif melebihi pendekatan krisis, remidial, dan preventif (Kartadinata, 2003).

Asumsi dasar pendekatan
Bimbingan dan $\begin{array}{r}\text { konseling } \\ \text { perkembangan adalah pemikiran }\end{array}$
bahwa perkembangan individu yang
sehat akan terjadi dalam interaksi
yang sehat individu dengan
lingkungannya. Dengan kata lain,
lingkungan tersebut bagi individu
menjadi lingkungan belajar. "Being


educate for its proportional emphasis is on prevention and improvement, not corective and therapeutic, Being developmental for its main goal of counseling is to develop humaan capacity by providing developmental environment" (Myrick, 2011). Kata sehat dalam hal ini bukan hanya merujuk pada interaksi antara individu dan lingkungan, tetapi lingkungan itu sendiri juga harus sehat.

Bimbingan dan konseling perkembangan dengan demikian dapat dartikan sebagai perspektif, pendekatan dalam bimbingan dan konseling yang berlandaskan pada teori-teori perkembangan dan bertujuan mengembangkan individu ke arah perkembangan optimal dalam lingkungan perkembangan yang mendukung.

Pengembangan lingkungan belajar yang kondusif dalam mereduksi sikap negatif siswa tentng seks bebas daapat melalui beberapa strategi layanan bimbingan dan konseling. Guru bimbingan dan konseling dapat melakukan layanan dasar. Strategi layanann dasar berupa bimbingan klasikal dan bimbingan kelompok. Materi yang diberikan tentan pubertas, organ reproduksi, serta bahaya seks bebas. Selain itu dapat mengembangkan media inovatif berupa video edukasi, macomediaflash, serta bentuk media lain tentang "say no to free sex".

Layanan responsif dapat berupa konseling individu dan kelompok serta konseling teman sebaya. Konseling teman sebaya merupakan suatu bentuk hubungan yang bersifat membantu. Makna bantuan disini yaitu sebagai upaya untuk membantu orang lain agar ia mampu tumbuh kearah yang dipilihnya sendiri, mampu memecahkan masalah yang dihadapinya dan mampu menghadapi krisis-krisis yang dialami dalam kehidupannya. Melalui kegiatan konseling teman sebaya, diharapkan mampu mencegah atau mampu memulihkan berbagai masalah perilaku seks bebas secara efektif sehingga dapat mengembangkan sikap positif terhadap perilaku seksual remaja disekolah menegah pertama.

Dukungan sistem, sebagai proses bantuan atau fasilitasi atau dukungan secara tidak langsung terhadap kelancaran, efektivitas dan efisisen pelaksanaan layanan bimbingan dan konseling. Strategi layanan dukungan sistem dalam mereduksi sikap negatif tentang seks bebas dapat berupa kolaborasi dengan berupa "parenting class' memberikan mentoring bagi orangtua tentang bagaimana mendampingi anak usia remaja. kolaborasi dengan BKKKBN dan Puskesmas tentang bahaya Seks bebas.

\section{SIMPULAN}

Hasil penelitian ini, diperoleh data bahwa siswa SMP di Kabupaten Sleman lebih dari 50\% responden memiliki sikap yang setuju terhadap seks bebas. Dari aspek biologis, 71\% responden tergolong sangat setuju terhadap perilaku seks bebas, 55\% tergolong sangat setuju dari aspek psikologis dan $61 \%$ sangat setuju dari aspek sosial. Ini berarti bahwa 
sebagian besar responden yaitu siswa SMP di Kabupaten Sleman memiliki sikap yang kurang baik terhadap perilaku seks bebas.

Bimbingan dan konseling bertujuan memfasilitasi siswa dapat berkembang optimal. Pengembangan lingkungan belajar yang kondusif dalam mereduksi sikap negatif siswa tentng seks bebas daapat melalui beberapa strategi layanan bimbingan dan konseling. Bentuk fasilitasi mengembnagkan siswa melalaui empat komponen layanan yaitu layanan dasar, responsif, peminatan perencanaan individual dan dukungan sistem. Strategi layanan bimbingan dan konseling yang dapat digunakan dalam mereduksi sikap negatif siswa adalah layanan dasar seperti bimbingann klasikal, bimbingan kelompok dan pengembangan media inovatif. Layanan responsif seperti konseling individu, konseling kelompok dan konseling sebaya. Dukungan sistem dapat berupa parenting class bagi orangtua tentang bagaimana pendampingan anak usia remaja, melakukan kolaborasi dengan BKKKBN dan Puskesmas tentang bahaya seks bebas.

\section{DAFTAR PUSTAKA}

American School Counselor Association. (2012). The ASCA National Model: A Frame work For School Counseling Program. Third Edition. Alexandria, VA: Author.

Caraka, P. B., \& Nindiya, E. S. (2015, October). Implementasi Permendikbud
RI Nomor 111 Tahun 2014

Dalam Pengembangan

Layanan BK di Sekolah Menengah. In Prosiding Seminar Nasional Bimbingan Dan Konseling (pp. 55-61).

Depdiknas. (2008). Penataan Pendidikan Profesional Konselor dan Layanan Bimbingan dan Konseling Dalam Jalur Pendidikan Formal. Jakarta : Depdiknas.

Dictionary, W. (2012). MerriamWebster Online Dictionary.

Fathur Rahman. (2012). Manajemen dan Pengembangan Program Bimbingan Konseling. Yogyakarta : Modul Pendidikan dan Latihan Profesi Guru Rayon 111 Universitas Negeri Yogyakarta.

Hidayat, Dede Rahmat. (2013). Bimbingan Konseling: Kesehatan Mental Di sekolah. Bandung : Remaja Rosda Karya.

Hunainah. (2011). Teori dan Implementasi Model Konseling Sebaya. Bandung: RIZQI PRESS.

Juntika. (2011). Membangun Peradaban Bangsa Indonesia Melalui Pendidikan dan Komprehensif Bermutu. Disampaikan dalam pidato Pengukuhan Prof. Dr. $\mathrm{H}$. Juntika, M.Pd sebagai Guru Besar/Profesor dalam Bidang Bimbingan dan Konseling Pada Fakultas Ilmu Pendidikan Universitas Pendidikan Indonesia. 
Kartadinata, S. (2011). Menguak Tabir Bimbingan dan Konseling sebagai Upaya Pedagogis.Bandung: UPI Press.

Kartadinata, S. (2003). Inventori Tugas

Perkembangan. Bandung:

Lab. PPB-UPI Bandung.

Myrick, Robert D. (2011). Developmental Guidance and Counseling : A Practical Approach Fifth edition. Minneapolis : Educational Media Corporation.

Notoatmodjo, G. (2007). Exploring the 'Weakest Link': A Study of Personal Password Security (Doctoral dissertation, The University of Auckland, New Zealand).

Peraturan Menteri Pendidikan dan Kebudayaan RI Nomor 111 Tahun 2014 tentang Bimbingan dan Konseling Pada Pendidikan Dasar dan Pendidikan Menengah.

Santoadi, Fajar. (2010). Manajeman Bimbingan dan Konseling
Komprehensif. Yogyakarta : Universitas Sanata Dharma.

Soetjiningsih, S. (2004). Tumbuh Kembang Remaja dan Permasalahannya. Sagung Seto. Jakarta, 320.

Susilarti, E., \& Sustiwi, F. (2005). "Tahun 2004, 560 Remaja Hamil Kecelakaan" dalam. Harian Kedaulatan Rakyat.

Supriatna, Mamat. (2011). Bimbingan dan Konseling Berbasis Kompetensi. Jakarta: PT Rajagrafindo Persada.

Undang-Undang Republik Indonesia Nomor 20 Tahun 2003 tentang Sistem Pendidikan Nasional

Villarruel, F. A., Perkins, D. F., Borden, L. M., \& Keith, J. G. (Eds.). (2003). Community youth development: Programs, policies, and practices. Sage Publications.

Yusuf, S., \& Nurihsan, J. (2008). Teori kepribadian. Bandung: Remaja Rosdakarya. 